\title{
Preliminary Correlation Map of Geomorphic Surfaces in North-Central Frenchman Flat, Nevada Test Site
}

\author{
Prepared by \\ Bechtel Nevada \\ Geotechnical Sciences \\ Las Vegas, Nevada
}

Prepared for

U.S. Department of Energy

National Nuclear Security Administration

Nevada Site Office

Las Vegas, Nevada

August 2005 


\section{DISCLAIMER STATEMENT}

Reference herein to any specific commercial product, process, or service by trade name, trademark, manufacturer, or otherwise, does not necessarily constitute or imply its endorsement, recommendation, or favoring by the U.S. Government or any agency thereof. The views and opinions of authors expressed herein do not necessarily state or reflect those of the U.S. Government or any agency thereof

\section{AVAILABILITY STATEMENT}

Available for sale to the public from-

U.S. Department of Commerce

National Technical Information Service

5285 Port Royal Road

Springfield, VA, 22161-0002

Telephone: 800.553.6847

Fax: 703.605.6900

E-mail: orders@ntis.gov

Online ordering: http://www.ntis.gov/ordering.htm

Available electronically at http://www.osti.gov/bridge.

Available for a processing fee to U.S. Department of Energy and its contractors, in paper, from-

U.S. Department of Energy

Office of Scientific and Technical Information

P.O. Box 62

Oak Ridge, TN 37831-0062

Telephone: 865.576.8401

Fax: 865.576.5728

E-mail: reports@adonis.osti.gov 


\title{
Preliminary Correlation Map of Geomorphic Surfaces in North-Central Frenchman Flat, Nevada Test Site
}

\author{
Prepared by \\ Bechtel Nevada \\ Geotechnical Sciences \\ Las Vegas, Nevada \\ Prepared for \\ U.S. Department of Energy \\ National Nuclear Security Administration \\ Nevada Site Office \\ Las Vegas, Nevada
}

August 2005 
This page intentionally left blank. 


\section{Preliminary Correlation Map of Geomorphic Surfaces in North-Central Frenchman Flat, Nevada Test Site}

DOE/NV/11718--1097

\section{Preface}

Raytheon Services Nevada (RSN), predecessor to Bechtel Nevada, was among the entities responsible for characterizing the hydrogeology of the Area 5 Radioactive Waste Management Site (RWMS) at the Nevada Test Site for the U.S. Department of Energy in the early 1990s. Some of this work was documented in a series of unpublished maps and data reports. As part of Bechtel Nevada's current scope for closure planning for the Area 5 RWMS, these maps and data reports are being updated to current editorial standards for approval for public release so they will be accessible for public review and for citation in future documents.

The map in this document was prepared in 1993 by geoscientists of the RSN Environmental Restoration and Waste Management Division and the RSN subcontractor, Lockheed Environmental Systems and Technologies Company. This map is reproduced here unchanged since the 1993 effort, but an updated map legend is provided along with narrative information added to support the map data. 
This page intentionally left blank. 


\title{
Geomorphic Surface Maps of Northern Frenchman Flat, Nevada Test Site, Southern Nevada \\ DOE/NV/11718--1097
}

\begin{abstract}
This correlation map (scale $=1: 12,000$ ) presents the results of a mapping initiative that was part of the comprehensive site characterization required to operate the Area 5 Radioactive Waste Management Site, a low-level radioactive waste disposal facility located in northern Frenchman Flat at the Nevada Test Site. Eight primary map units are recognized for Quaternary surfaces: remnants of six alluvial fan or terrace surfaces, one unit that includes colluvial aprons associated with hill slopes, and one unit for anthropogenically disturbed surfaces.

This surficial geology map provides fundamental data on natural processes for reconstruction of the Quaternary history of northern Frenchman Flat, which in turn will aid in the understanding of the natural processes that act to develop the landscape, and the time-frames involved in landscape development.

The mapping was conducted using color and color-infrared aerial photographs and field verification of map unit composition and boundaries. Criteria for defining the map unit composition of geomorphic surface units are based on relative geomorphic position, landform morphology, and degree of preservation of surface morphology. The bedrock units identified on this map were derived from previous published mapping efforts and are included for completeness.
\end{abstract}


This page intentionally left blank. 


\section{Table of Contents}

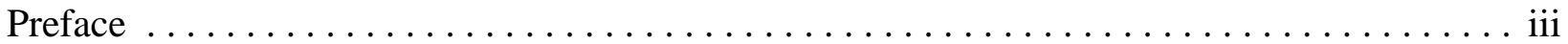

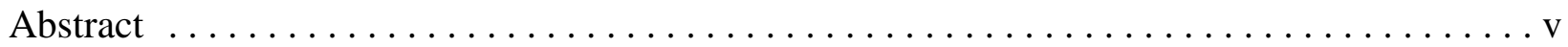

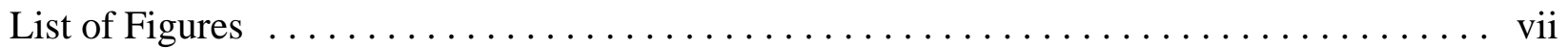

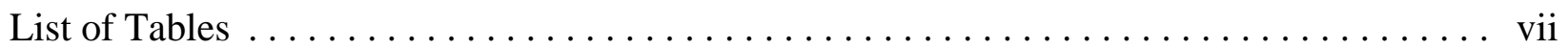

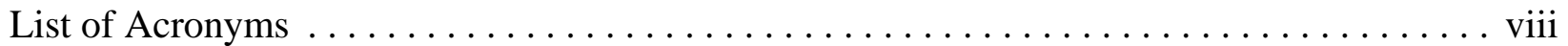

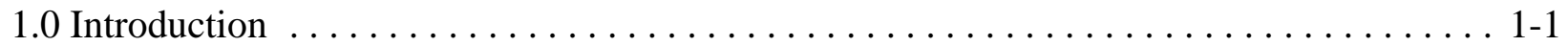

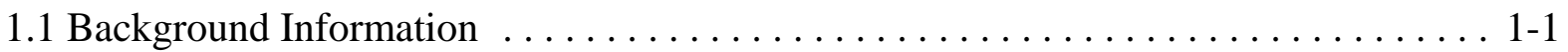

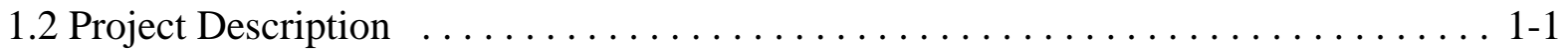

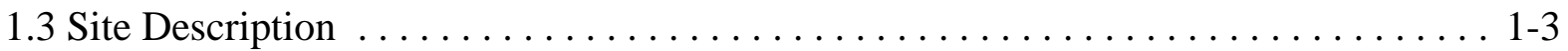

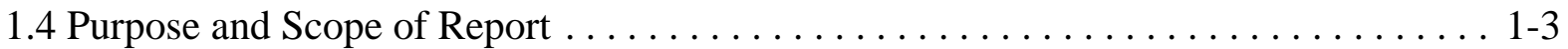

2.0 Methods ............................................... 2-1

2.1 Methods ........................................... 2-1

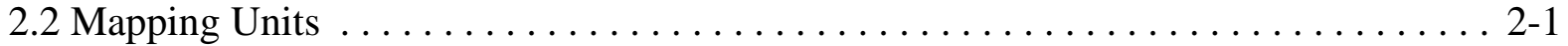

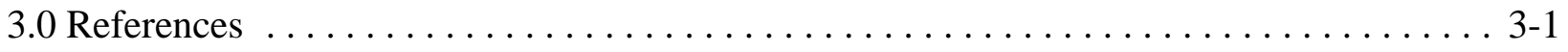

Map Legend

Distribution List

\section{List of Figures}

Number

Title

Page

1-1 Location of Preliminary Geomorphic Surface Map of North-Central

Frenchman Flat at the Nevada Test Site $\ldots \ldots \ldots \ldots \ldots \ldots \ldots \ldots \ldots . . . \ldots .2$

\section{List of Tables}

Number

Title

Page

$2-1$ Relative Occurrence of Selected Characteristics of Geomorphic Surface Map Units within Northern Frenchman Flat $\ldots . \ldots \ldots . . . . . . .2-2$ 


\section{List of Acronyms and Abbreviations}

$\mathrm{BN}$

Bechtel Nevada

DOE

U.S. Department of Energy

NTS Nevada Test Site

RSN Raytheon Services Nevada

RWMS Radioactive Waste Management Site

USGS U.S. Geological Survey 


\subsection{Introduction}

\subsection{Background Information}

Raytheon Services Nevada (RSN), a predecessor to Bechtel Nevada (BN), was among the entities responsible for characterizing the hydrogeology of the Area 5 Radioactive Waste Management Site (RWMS) at the Nevada Test Site (NTS). This work was conducted in 1993 for the U.S. Department of Energy, National Nuclear Security Administration Nevada Site Office (formerly U.S. Department of Energy [DOE], Nevada Operations Office) Waste Management Division.

Some of this work was documented in a series of unpublished maps and data reports. As part of Bechtel Nevada's current scope for closure planning for the Area 5 RWMS, these maps and data reports are being updated to current editorial standards for approval for public release so they will be accessible for public review and for citation in future documents.

The map in this document was prepared by S. E. Rawlinson and D. L. Gustafson of the RSN Environmental Restoration and Waste Management Division (now of BN) and K. E. Snyder of the RSN subcontractor, Lockheed Environmental Systems and Technologies Company.

\subsection{Project Description}

This surficial geology map (scale $=1: 12,000$ ) of north-central Frenchman Flat was developed in 1993 as part of comprehensive site characterization required to operate the Area 5 RWMS, a low-level radioactive waste disposal facility located in northern Frenchman Flat. The region mapped is included within the area defined by the following latitude and longitude coordinates, and is shown in Figure 1-1:

$\begin{array}{ll}\text { Eastern Boundary: } & 115^{\circ} 53^{\prime} 58^{\prime \prime} \\ \text { Western Boundary: } & 116^{\circ} 00^{\prime}, 299^{\prime \prime} \\ \text { Northern Boundary: } & 36^{\circ} 57^{\prime} 59^{\prime} \\ \text { Southern Boundary: } & 36^{\circ} 50^{\prime}, 53^{\prime \prime}\end{array}$

Seven smaller scale maps $(1: 6,000)$ that cover this area were produced in 1995 to provide more detail (BN, 2005). This map shows the main surficial features at a larger, more convenient scale on one sheet.

The data produced by these mapping efforts provides fundamental information on natural processes that can be used to reconstruct the Quaternary history of northern Frenchman Flat. Reconstruction of the Quaternary history provides an understanding of the natural processes that act to develop the landscape, and the time-frames involved in landscape development. 


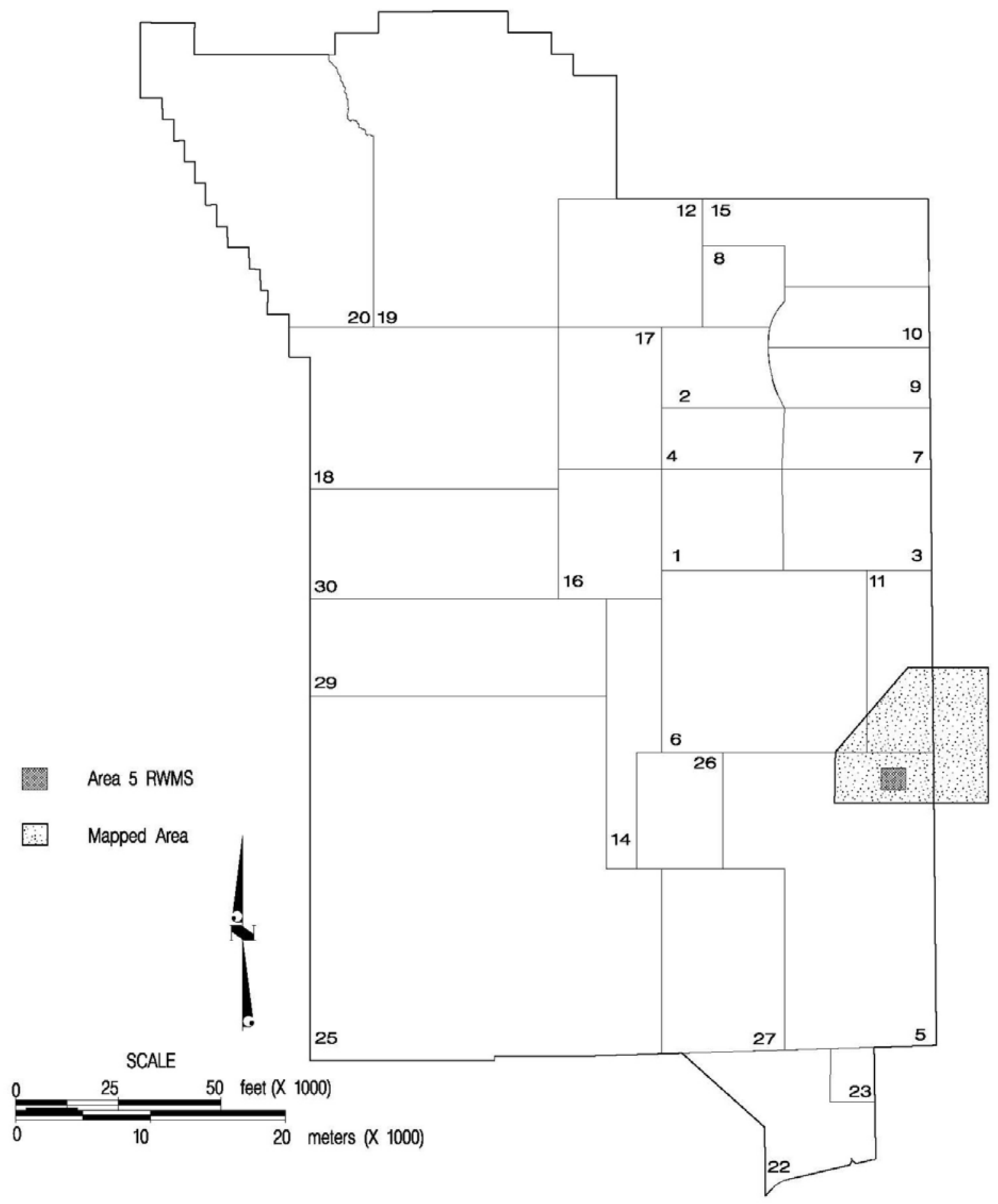

Figure 1-1

Location of Map Area in Frenchman Flat at the Nevada Test Site 


\subsection{Site Description}

The Area 5 RWMS is located within the northeast part of Frenchman Flat, in the northern portion of the Mojave desert (DOE, 2004). Annual precipitation for Frenchman Flat is approximately 12 centimeters (5 inches) (DOE, 1998). Precipitation in the area is sporadic, typically falling as small amounts of rain or snow during isolated, short-duration winter and summer storms. Severe weather can occur in the region, usually in the form of summer thunderstorms with intense lightning, strong winds, and localized heavy rainfall.

Frenchman Flat is an intermontane basin located in Basin and Range physiographic province. The sparsely vegetated valley floor slopes gently toward a central playa (dry lake bed). Ground level elevations range from 938 meters (3,078 feet) above sea level at the playa, to over 1,463 meters ( 4,800 feet) in the nearby surrounding highlands.

\subsection{Purpose and Scope of Report}

This report presents a preliminary correlation map of the surficial geology of the study area, available on paper at a size of approximately 91 centimeters (36 inches) square and in electronic form. Also included is a brief narrative (this document) describing the rationale and methods for the mapping project. The map legend provided at the end of this narrative includes detailed descriptions of the mapping units as well as information for correlating the 1993 map units with modern stratigraphic nomenclature from Slate et al. (1999) for these units. 
This page intentionally left blank. 


\subsection{Methods}

\subsection{Methods}

The mapping was conducted using color and color-infrared, 1:24,000-scale aerial photographs taken in August 1991 by EG\&G Energy Measurements, Inc. The ground control for the topographic contours was taken from U.S. Geological Survey (USGS) topographic maps (USGS, 1986a; 1986b).

Map unit composition and boundaries were verified in the field. Available pit and trench walls at the Area 5 RWMS and nearby areas were also mapped and sampled to obtain detailed nearsurface information about the Quaternary alluvium and to check for the presence of faults.

\subsection{Mapping Units}

The map shows the extent of the eight units used to map Quaternary surfaces in the study area. These units were defined and identified on the basis of bounding discontinuities, which may be either disconformities or buried soils. Criteria for defining the map unit composition of geomorphic surface units are based on relative geomorphic position, landform morphology, and degree of preservation of surface morphology.

The eight geomorphic surfaces mapped (Units Q2 through Q7, Qcu, and Qd) span the time from the early Quaternary to the present. This correlation of geomorphic surfaces was based on the preliminary photo-interpretation of surficial geology by Rawlinson (1991). Each geomorphic surface exhibits a distinctive degree of six geologic characteristics: desert pavement, carbonate and/or silica platelets on the surface, varnished clasts, rubified clasts, preserved bar-and-swale morphology, and an eolian mantle (Table 2-1). The unit definitions were adapted from Gibson et al. (1992) and Wesling et al. (1992), who performed similar mapping work in the nearby Midway Valley at the NTS. Detailed descriptions of all the geomorphic surface mapping units are provided in the legend at the end of this report.

Geomorphic surface mapping units Q7 (youngest) through Q3 are generally present throughout most of the map area. Units Q2 and Qcu are generally not extensive and are restricted to mountain front or upper alluvial fan locations. This map also indicates the location and extent of disturbed areas (Unit Qd) and surfaces cut in bedrock units.

Bedrock units shown on this map are primarily Tertiary volcanic rocks and the Ordovician Antelope Valley Limestone. The stratigraphic symbols used for the bedrock units for the 1993 map were modified from Hinrichs and McKay (1965), Poole (1965), Poole et al. (1965), and Rawlinson (1991). The updated stratigraphic nomenclature for the bedrock units, modified from Slate et al. (1999), is listed in the legend with the older unit names for the convenience of the reader. 
Table 2-1

Relative Occurrence of Selected Characteristics of Geomorphic Surface Map Units within Northern Frenchman Flat

\begin{tabular}{|c|c|c|c|c|c|c|}
\hline \multirow{2}{*}{$\begin{array}{c}\text { Geologic } \\
\text { Characteristic }\end{array}$} & \multicolumn{6}{|c|}{ Geomorphic Surface Map Unit } \\
\hline & Q2 & Q3 & Q4 & Q5 & Q6 & Q7 \\
\hline Desert pavement & $\bullet \bullet \bullet \bullet$ & $\bullet \bullet \bullet \bullet$ & $\begin{array}{l}\bullet \bullet \\
\text { to } \\
\bullet \bullet \bullet\end{array}$ & $\begin{array}{l}\bullet \\
\text { to } \\
\bullet \bullet\end{array}$ & N.O. & N.O. \\
\hline $\begin{array}{l}\text { Carbonate/silica } \\
\text { platelets on surface }\end{array}$ & $\bullet \bullet$ & $\bullet \bullet$ & $\bullet$ & N.O. & N.O. & N.O. \\
\hline Varnished clasts & $\bullet \bullet \bullet \bullet$ & $\bullet \bullet \bullet \bullet$ & $\begin{array}{l}\bullet \bullet \\
\text { to } \\
\bullet \bullet \bullet\end{array}$ & $\bullet \bullet$ & $\bullet$ & N.O. \\
\hline Rubified clasts & $\bullet \bullet \bullet \bullet$ & $\bullet \bullet \bullet \bullet$ & $\begin{array}{l}\bullet \bullet \\
\text { to } \\
\bullet \bullet \bullet\end{array}$ & $\bullet \bullet$ & $\bullet$ & N.O. \\
\hline $\begin{array}{l}\text { Bar-and-swale } \\
\text { morphology preserved }\end{array}$ & $\bullet$ & $\bullet$ & $\bullet \bullet$ & $\bullet \bullet \bullet$ & $\bullet \bullet \bullet \bullet$ & $\bullet \bullet \bullet \bullet$ \\
\hline Eolian mantle & $\begin{array}{c}\bullet \bullet \bullet \\
\text { to } \\
\bullet \bullet \bullet \bullet\end{array}$ & $\begin{array}{c}\bullet \bullet \bullet \\
\text { to } \\
\bullet \bullet \bullet \bullet\end{array}$ & $\begin{array}{l}\bullet \bullet \\
\text { to } \\
\bullet \bullet \bullet\end{array}$ & $\begin{array}{c}\bullet \\
\text { to } \\
\bullet\end{array}$ & $\bullet$ & N.P. \\
\hline
\end{tabular}

Notes:

Adapted from Gibson et al. (1992).

Unit Qcu had not been studied to the same extent as the other mapping units at the time this map was made, and is not included on this table.

Dots $(\bullet)$ show the typical, relative development of selected geologic and geomorphic characteristics for the mapping units.

Geologic and Geomorphic Characteristics:

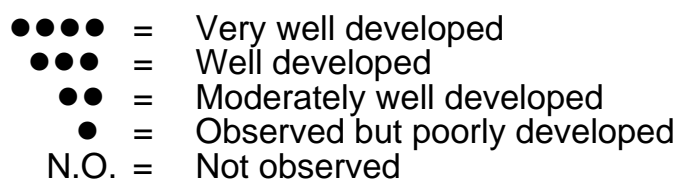

Dots $(\bullet)$ indicate relative thickness of eolian mantle:

$$
\begin{aligned}
\bullet \bullet \bullet \bullet & =\text { Very thick } \\
\bullet \bullet \bullet & =\text { Thick } \\
\bullet \bullet & =\text { Thin } \\
\bullet & =\text { Very thin } \\
\text { N.P. }= & \text { Not present }
\end{aligned}
$$




\subsection{References}

Bechtel Nevada, 2005. Geomorphic Surface Maps of Northern Frenchman Flat, Nevada Test Site, Southern Nevada. Prepared for U.S. Department of Energy. Report

DOE/NV/11718--1091. Las Vegas, NV.

BN, see Bechtel Nevada.

DOE, see U.S. Department of Energy.

Gibson, J. D., J. R. Wesling, F. H. Swan, and T. F. Bullard, 1992. Recent Characterization Activities of Midway Valley as a Potential Repository Surface Facility Site. Sandia National Laboratories Report SAND92-0091C, Albuquerque, NM. 20 pp.

Hinrichs, E. N., and E. J. McKay, 1965. Geologic Map of the Plutonium Valley Quadrangle, Nye and Lincoln Counties, Nevada. U.S. Geological Survey Geologic Quadrangle Map GQ-384, scale 1:24,000.

Poole, F.G. 1965. Geologic Map of the Frenchman Flat Quadrangle, Nye, Lincoln, and Clark Counties, Nevada. U.S. Geological Survey Geologic Quadrangle Map GQ-456, scale $1: 24,000$.

Poole, F.G., D.P. Elston, and W.J. Carr. 1965. Geologic Map of the Cane Spring Quadrangle, Nye County, Nevada. U.S. Geological Survey Geologic Quadrangle Map GQ-455, scale 1:24,000.

Rawlinson, S. E., 19991. "Preliminary Photointerpretative Surficial Geology Map of NorthCentral Frenchman Flat, Nevada Test Site.” In: Surficial Geology of the Area 5 Radioactive Waste Management Site and Vicinity, Nevada Test Site. Raytheon Services Nevada Report. Las Vegas, NV.

Slate, J. L., M. E. Berry, P. D. Rowley, C. J. Fridrich, K. S. Morgan, J. B. Workman, O. D. Young, G. L. Dixon, V. S. Williams, E. H. McKee, D. A. Ponce, T. G. Hildenbrand, WC Swadley, S. C. Lundstrom, E. B. Ekren, R. G. Warren, J. C. Cole, R. J. Fleck, M. A. Lanphere, D. A. Sawyer, S. A. Minor, D. J. Grunwald, R. J. Laczniak, C. M. Menges, J. C. Yount and A. S. Jayko, 1999. Digital Geologic Map of the Map of the Nevada Test Site and Vicinity, Nye, Lincoln, and Clark Counties, Nevada and Inyo County, California. U.S. Geological Survey Open-File Report 99B554BA, scale 1:120,000.

U.S. Department of Energy, Nevada Operations Office, 1998. Routine Radiological Environmental Monitoring Plan, Report DOE/NV/11718--244. Prepared by Bechtel Nevada. Las Vegas, NV.

U.S. Department of Energy, National Nuclear Security Administration Nevada Site Office, 2004. Nevada Test Site Environmental Report 2003. DOE/NV/11718--971. Prepared by Bechtel Nevada. Las Vegas, NV.

U.S. Geological Survey, 1986a. Topographic Map of the Frenchman Flat Quadrangle, Nevada Nye County. Scale $=1: 24,000$.

U.S. Geological Survey, 1986b. Topographic Map of the Plutonium Valley Quadrangle, Nevada - Nye County. Scale =1:24,000. 
USGS, see U.S. Geological Survey.

Wesling, J. R., T. F. Bullard, F. H. Swan, R. C. Perman, M. M. Angell, and J. D. Gibson, 1992. Preliminary Mapping of Surficial Geology of Midway Valley, Yucca Mountain Project, Nye County, Nevada. Interim Data Report: Sandia National Laboratories Report SAND91-0607. 


\section{Legend for Preliminary Correlation Map of Geomorphic Surfaces in North-Central Frenchman Flat, Nevada Test Site}

\begin{tabular}{|c|c|c|}
\hline $\begin{array}{c}\text { Map } \\
\text { Unit } \\
\text { Symbol } \\
\end{array}$ & $\begin{array}{l}\text { Current } \\
\text { Unit Map } \\
\text { Symbola }^{\text {a }} \\
\end{array}$ & Unit Description \\
\hline Q7 & 7 & $\begin{array}{l}\text { Unit Q7 (Late Holocene) consists of fine to medium sand, sandy gravel, or both, } \\
\text { deposited by fluvial processes and located in confined active channels or on } \\
\text { active parts of fans. Rock fragments range between pebbles and large boulders. } \\
\text { Clasts are subangular to subrounded. The largest clasts tend to be concentrated } \\
\text { along the sides of channels or are covered by finer-grained sediments in channel } \\
\text { bottoms. Deposits are typically planar-bedded, but may be cross-bedded or } \\
\text { massive, depending on the sediment transport mechanism. The original bar-and- } \\
\text { swale relief is unaltered. Surfaces are barren or sparsely vegetated, show no soil } \\
\text { or pavement development, and are the youngest surfaces in the area. Included } \\
\text { in Q7 are areas of Q6 too small to map. }\end{array}$ \\
\hline Q6 & 6 & $\begin{array}{l}\text { Unit Q6 (Holocene) consists of fine to medium sand, sandy gravel, or both, } \\
\text { deposited by fluvial processes. The unit occurs along the active washes as low } \\
\text { (less than } 1 \text { meter) flood plains, and as vegetated bars along washes. Surface } \\
\text { relief reflects preservation of original bar-and-swale morphology. Rock fragments } \\
\text { range between pebbles and large boulders. Clasts are subangular to } \\
\text { subrounded. Deposits are typically planar-bedded, but may be cross-bedded or } \\
\text { massive, depending on the sediment transport mechanism. Surfaces are } \\
\text { sparsely vegetated and show very little or no pavement or soil development. } \\
\text { Included in Q6 are areas of Q7 too small to map. Unit Q6 is the second-youngest } \\
\text { of the map units. }\end{array}$ \\
\hline Q5 & 5 & $\begin{array}{l}\text { Unit Q5 (Late Pleistocene to Holocene) consists of fine to medium sand, sandy } \\
\text { gravel, or both, deposited by fluvial processes. The surface of Q5 displays typical } \\
\text { bar-and-swale morphology. Rock fragments range between pebble and large } \\
\text { boulders. Clasts are subangular to subrounded. Deposits are typically planar- } \\
\text { bedded, but may be cross-bedded or massive, depending on the sediment } \\
\text { transport mechanism. Surface are typically less than } 1 \text { meter above any adjacent } \\
\text { Q6 or Q7 surfaces. Surfaces are vegetated and may show a weakly formed } \\
\text { desert pavement, rock varnish, and soil development. Included in Q5 are incised } \\
\text { channels and wide swales of younger units too small to map. }\end{array}$ \\
\hline Q4 & 4 & $\begin{array}{l}\text { Unit Q4 (Late Pleistocene) consists of fine to medium sand, sandy gravel, or } \\
\text { both, deposited by fluvial processes adjacent to active channels and as fan and } \\
\text { valley-fill alluvium. Rock fragments range between pebbles and large boulders. } \\
\text { Clasts are subangular to subrounded. Overbank deposits commonly overlie } \\
\text { gravel deposits. Deposits are typically planar-bedded, but may be cross-bedded } \\
\text { or massive depending on the sediment transport mechanism. Surfaces are } \\
\text { typically less than } 2 \text { meters above adjacent Q5 or Q6 surfaces. Surfaces have } \\
\text { moderately dense vegetation. Desert pavement formed on Q4 may be } \\
\text { moderately developed, but not as well packed as pavements found on older Q3 } \\
\text { and Q2 surfaces. Clasts are moderately to well varnished on surface that have a } \\
\text { well-developed pavement. Bar-and-swale relief on Q4 has been reduced to clast } \\
\text { height above the surface, and shows some soil development. Included in Q4 are } \\
\text { incised channels and wide swales of younger units too small to map. }\end{array}$ \\
\hline Q3 & 3 & $\begin{array}{l}\text { Unit Q3 (Middle to Late Pleistocene [?]) consists of fine to medium sand, sandy } \\
\text { gravel, or both, deposited by fluvial processes. Colluviation may contribute some } \\
\text { sediment in toe-slope positions. Rock fragments range between pebbles and } \\
\text { large boulders. Clasts are angular to subrounded. Deposits are typically planar- } \\
\text { bedded, but may be cross-bedded or massive, depending on the sediment } \\
\text { transport mechanism. Unit Q3 deposits commonly show interbeds of caliche or } \\
\text { zones of calcrete. Surfaces have moderately dense vegetation, and may show } \\
\text { well-developed desert pavement and varnished clasts. The original depositional } \\
\text { bar-and-swale morphology has been reduced to the height of individual clasts } \\
\text { above the surface. Included in Q3 are incised channels and wide swales of } \\
\text { younger units too small to map. }\end{array}$ \\
\hline
\end{tabular}




\section{Legend for Preliminary Correlation Map of Geomorphic Surfaces in North-Central Frenchman Flat, Nevada Test Site (continued)}

\begin{tabular}{|c|c|c|}
\hline $\begin{array}{c}\text { Map } \\
\text { Unit } \\
\text { Symbol }\end{array}$ & $\begin{array}{l}\text { Current } \\
\text { Unit Map } \\
\text { Symbol }^{a}\end{array}$ & Unit Description \\
\hline Q2 & 2 & $\begin{array}{l}\text { Unit Q2 (Middle Pleistocene) consists of fine to medium sand, sandy gravel, or } \\
\text { both. Rock fragments range between pebbles and large boulders. Clasts are } \\
\text { angular to subrounded. Deposits are typically planar-bedded, but may be cross- } \\
\text { bedded or massive, depending on the sediment transport mechanism, and } \\
\text { commonly show interbeds of caliche or zones of calcrete. Surfaces are typically } \\
\text { more than } 2 \text { meters above adjacent Q3 deposits in the middle or proximal fan } \\
\text { zones. Surface have moderately dense vegetation, and commonly include soil, } \\
\text { pavement, and varnish development. Unit Q2 may be incised by younger } \\
\text { surfaces that are as much as several meters deep and are too small to map. }\end{array}$ \\
\hline Qcu & Qai(?) $^{\mathrm{b}}$ & $\begin{array}{l}\text { Unit Qcu (Holocene to Late Pleistocene) consists of colluvium and debris flows } \\
\text { that mantle the lower hill slopes surrounding Frenchman Flat. Deposits are sand } \\
\text { or sandy gravel, or both. Rock fragments range between pebbles and large } \\
\text { bounders. Clasts are angular to subrounded, with subangular clasts most } \\
\text { common. Deposits are typically massive, but may be poorly bedded in down- } \\
\text { slope positions from re-transport by sheet flow. Surfaces show little to } \\
\text { moderately dense vegetation, and commonly show poor to moderate soil } \\
\text { development, pavement, and varnished clasts. }\end{array}$ \\
\hline Qd & d & Unit Qd (Late Holocene) consists of any deposits emplaced by cutting or filling. \\
\hline Qtb & Tybf & $\begin{array}{l}\text { Basalt of Frenchman Flat (Quaternary). Bluish-black, fine-grained olivine basalt } \\
\text { dikes and sills. }\end{array}$ \\
\hline & Tma & $\begin{array}{l}\text { Timber Mountain Group (Tertiary) }{ }^{\mathrm{c}} \\
\text { Ammonia Tanks Tuff. Grayish-brown, densely welded devitrified, ash-flow } \\
\text { tuff with conspicuous biotite. }\end{array}$ \\
\hline Tpat1 & Tma & $\begin{array}{l}\text { Ammonia Tanks Tuff. Gray, densely welded, devitrified ash-flow tuff. Grades } \\
\text { downward through brown, vitric, partially welded tuff. Locally, unit is entirely } \\
\text { brown, partially welded tuff with large fragments of pale olive-tan pumice. }\end{array}$ \\
\hline & $\mathrm{Tmr}$ & $\begin{array}{l}\text { Rainier Mesa Tuff. Pale-gray, devitrified, partially welded tuff with porous } \\
\text { vapor-phase zone at top. Weathers to bench and steep slope covered with } \\
\text { desert-varnished boulders. }\end{array}$ \\
\hline Tpr1 & Tmr & $\begin{array}{l}\text { Rainier Mesa Tuff. Gray and purplish-brown, densely welded, devitrified ash- } \\
\text { flow tuff. Grades downward through pink, partially welded, vitric tuff to pale- } \\
\text { gray nonwelded ash-flow tuff. Weathers to a steep slope littered with platy } \\
\text { fragments above discontinuous knobby columns and low cavernous cliffs. }\end{array}$ \\
\hline Tpra & Tmr & $\begin{array}{l}\text { Rainier Mesa Tuff. Ash-fall tuff, yellow and gray zeolitic bedded tuff; small } \\
\text { amount of pale-gray vitric tuff. Weathers to a slope. }\end{array}$ \\
\hline Tpt & Tpt & $\begin{array}{l}\text { Paintbrush Group (Tertiary) } \\
\text { Topopah Spring Tuff. Multiple-flow, simple cooling unit; chiefly brown, } \\
\text { welded, devitrified and black vitrophyric ash-flow tuff. Includes rhyolitic } \\
\text { bedded tuff and possibly minor nonwelded ash-flow tuff, generally zeolitized. } \\
\text { [Paintbrush Tuff, Poole, 1965]. }\end{array}$ \\
\hline Tps & Th & $\begin{array}{l}\text { Calico Hills Formation (Tertiary) } \\
\text { Pale gray and brown, vitric bedded tuff. Many cycles made up of brown, } \\
\text { chiefly fine but also poorly sorted tuff, in beds } 0.3 \text { to } 1.2 \text { meters thick, } \\
\text { underlain by pale gray, fine to lapilli, thin-bedded, medium to well-sorted tuff. } \\
\text { [Survey Butte (?) Member, Hinrichs and McKay, 1965] }\end{array}$ \\
\hline
\end{tabular}




\section{Legend for Preliminary Correlation Map of Geomorphic Surfaces in North-Central Frenchman Flat, Nevada Test Site (continued)}

\begin{tabular}{|c|c|c|}
\hline $\begin{array}{c}\text { Map } \\
\text { Unit } \\
\text { Symbol }\end{array}$ & $\begin{array}{l}\text { Current } \\
\text { Unit Map } \\
\text { Symbol }^{a} \\
\end{array}$ & Unit Description \\
\hline Twf & Tw & 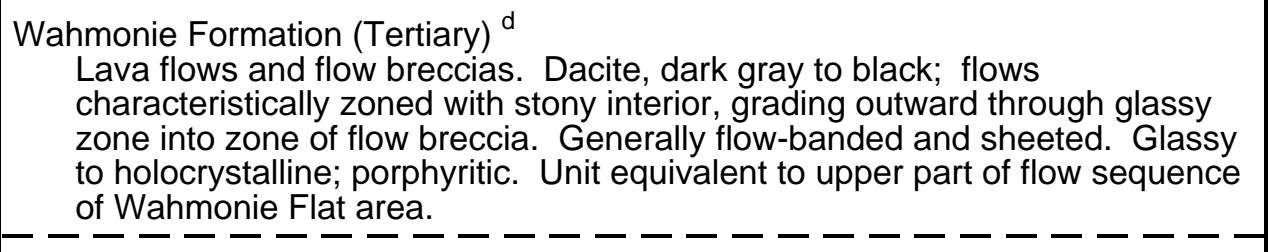 \\
\hline Twtb & Tw & $\begin{array}{l}\text { Tuff, sandstone, and lithic tuff breccia. Gray, white, and red laminated to very } \\
\text { thick-bedded, biotite-rich, pumiceous tuff, sandstone, and lithic tuff breccia. }\end{array}$ \\
\hline $\mathrm{Ti}$ & Th & $\begin{array}{l}\text { Calico Hills Formation (Tertiary) } \\
\text { Bedded tuff and tuffaceous sandstone. Tuff is gray, pink, and brown, and } \\
\text { most of it is zeolitic. Subordinate sandstone in reddish brown. } \\
\text { [Indian Trail (?) Formation, Hinrichs and McKay, 1965] }\end{array}$ \\
\hline Tms & Tws & $\begin{array}{l}\text { Wahmonie Formation (Tertiary) } \\
\text { Salyer Member. Tuff and tuffaceous rock. Reddish-brown tuffaceous } \\
\text { sandstone and siltstone; locally conglomeratic; gray, yellow, orange, and red } \\
\text { zeolitic and argillic bedded tuff, some biotite-rich. }\end{array}$ \\
\hline Tpa & Tgp & $\begin{array}{l}\text { Rocks of Pavits Spring (Tertiary) }{ }^{\mathrm{e}} \\
\text { Bedded tuff. Gray, yellow, and red, vitric and zeolitic; locally conglomeratic, } \\
\text { carbonaceous, and fossiliferous. }\end{array}$ \\
\hline Tpan & Tgp & $\begin{array}{l}\text { Nonwelded ash-flow (?) tuff. Gray, yellow, and brown, mostly zeolitic; slightly } \\
\text { flattened pumice. }\end{array}$ \\
\hline $\mathrm{Oa}$ & $\mathrm{Oa}$ & $\begin{array}{l}\text { Pogonip Group (Ordovician) } \\
\text { Antelope Valley Limestone. Medium gray, fine- to medium-crystalline, } \\
\text { sparsely fossiliferous; thin tan quartzite in upper part. }\end{array}$ \\
\hline
\end{tabular}

a Additional work in this area, documented on later maps (i.e., BN, 2005 for the Quaternary units; Slate et al., 1999 for the Tertiary and pre-Tertiary units) has resulted in renaming of some of the units used on this map. For the convenience of the reader, this chart may serve as a correlation of the mapping unit symbols used on this map and later maps of this area. The 1993 map terminology and original source for the Tertiary units is included in brackets [ ] for those units with major changes in nomenclature.

b Qcu does not correlate with Unit 1 of BN, 2005. May be included in Qai, Intermediate alluvial deposits, of Slate et al., 1999.

c Both Tpat1 and Tpat2 (Hinrichs and McKay, 1965) are now included in Tma. Tpr1, Tpr2, and Tpra (Hinrichs and McKay, 1965) are now included in Tmr.

d Both Twf and Twcb (Poole et al., 1965) and Tms (Tuffs and Tuffaceous Rocks of Mount Salyer [Hinrichs and McKay, 1965]) are now included in Tw.

e Both Tpa and Tpan (Tuff of Pavits Spring, Hinrichs and McKay, 1965) are included in Tgp. 


\section{Distribution List}

\section{U. S. Department of Energy}

Jhon Carilli

$\frac{\text { Copies }}{2}$

Waste Management Division

2

U.S. Department of Energy

National Nuclear Security Administration

Nevada Site Office

P.O. Box 98518, M/S 505

Las Vegas, NV 89193-8518

B. M. Crowe

Apogen Technologies

U.S. Department of Energy

National Nuclear Security Administration

Nevada Site Office

P.O. Box 98518, M/S 505

Las Vegas, NV 89193-8518

U.S. Department of Energy

1 (uncontrolled)

National Nuclear Security Administration

Nevada Site Office

Technical Library

P.O. Box 98518, M/S 505

Las Vegas, NV 89193-8518

U.S. Department of Energy

National Nuclear Security Administration

2 (electronic, uncontrolled)

Nevada Site Office

Nuclear Testing Archive

Public Reading Facility

P.O. Box 98518, M/S 400

Las Vegas, NV 89193-8518

U.S. Department of Energy

Office of Scientific and Technical Information

1 (electronic, uncontrolled)

Post Office Box 62

Oak Ridge, Tennessee 37831-0062 


\section{Distribution List (continued)}

\section{Bechtel Nevada}

\section{$\underline{\text { Copies }}$}

Max Dolenc

Bechtel Nevada

P.O. Box 98521, M/S NSF080

Las Vegas, NV 89193-8521

Environmental Management Library

Bechtel Nevada

P.O. Box 98521, NLV094

Las Vegas, NV 89193-8521

Steve Nacht

Bechtel Nevada

P.O. Box 98521, NSF083

Las Vegas, NV 89193-8521

Stuart Rawlinson

Bechtel Nevada

P.O. Box 98521, NTS416

Las Vegas, NV 89193-8521

Dan Tobiason

Bechtel Nevada

P.O. Box 98521, NTS416

Las Vegas, NV 89193-8521 


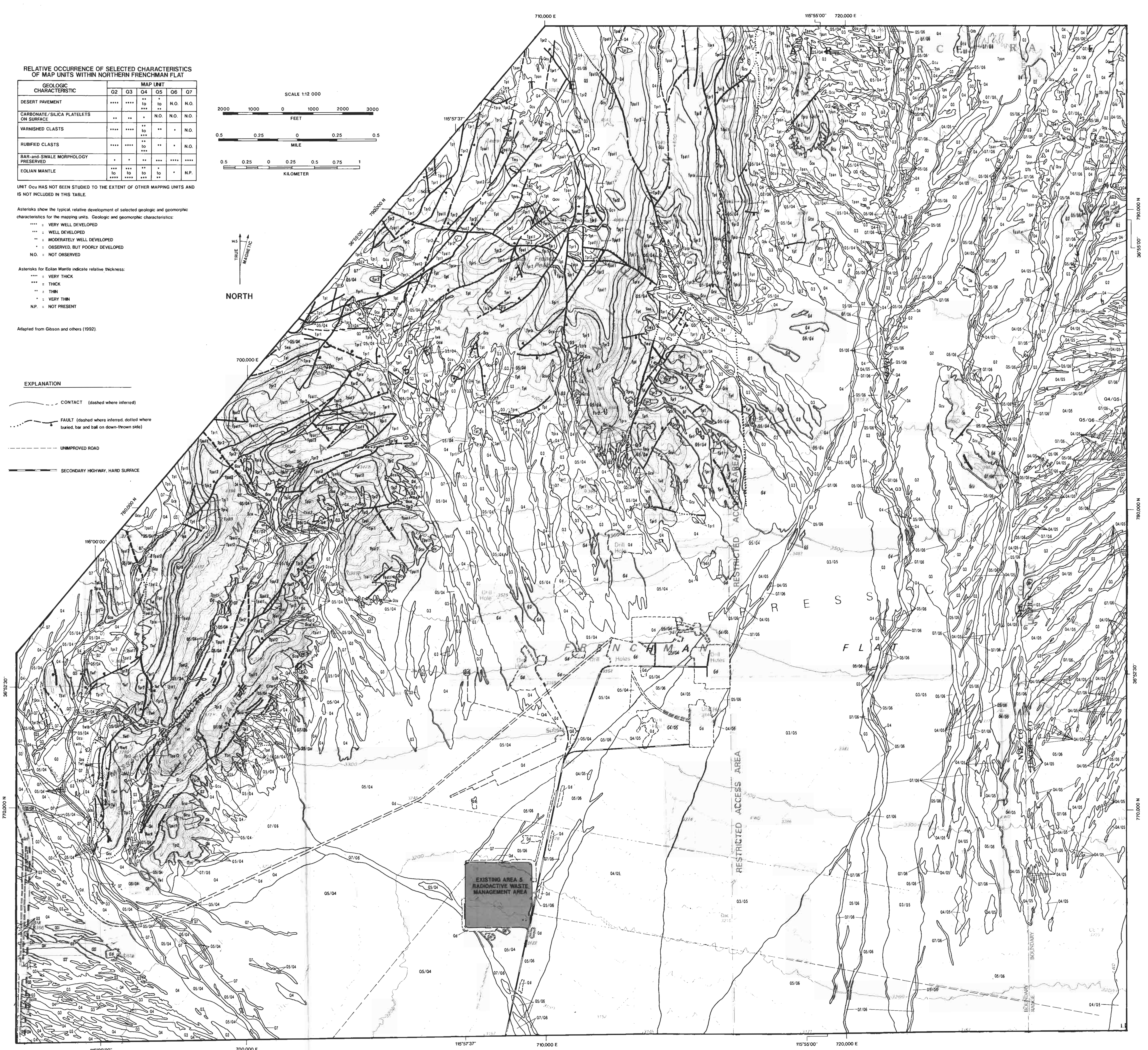

